\title{
Euastrum and Micrasterias (family Desmidiaceae) in lentic tropical ecosystem, Brazil
}

\author{
Francielle Karla Lopes da Silva ${ }^{1,2}$ \& Sirlene Aparecida Felisberto ${ }^{I}$ \\ ${ }^{1}$ Universidade Federal de Goiás, Instituto de Ciências Biológicas, Departamento de Biologia Geral, \\ Laboratório de Ficologia, CEP 74001-970, Goiânia, GO, Brazil. \\ ${ }^{2}$ Corresponding author: Francielle Karla Lopes da Silva, e-mail: franciellekls.bio@gmail.com
}

\begin{abstract}
SILVA, F.K.L., FELISBERTO, S.A. Euastrum and Micrasterias (family Desmidiaceae) in lentic tropical ecosystem, Brazil. Biota Neotropica. 15(1): e20140079. dx.doi.org/10.1590/1676-06032015007914
\end{abstract}

\begin{abstract}
This study aimed to perform the taxonomic survey of Euastrum and Micrasterias in a lentic tropical environment, seeking to contribute to the knowledge on biodiversity and geographical distribution of the Zygnemaphyceae. Conducted at the Samambaia Reservoir, ten samples were collected in the dry season (24/09/10 and 04/11/10) and ten in the rainy season (06/01/11 and 02/03/11). Periphyton was sampled from stems of aquatic plants (Cyperaceae), which were in the marginal area of the reservoir. With the floristic survey, 22 taxa were identified representing the genus Euastrum (9) and Micrasterias (13), of these 16 are new records for the State of Goiás. In relation the frequency of occurrence and the seasonal period, 19 taxa were classified in the rare category and three in common, nine species were recorded during the dry season, while four only in the rainy season.
\end{abstract}

Keywords: desmids, periphyton, sazonal, taxonomy, Zygnemaphyceae.

SILVA, F.K.L., FELISBERTO, S.A. Euastrum e Micrasterias (família Desmidiaceae) em ecossistema tropical lêntico, Brasil. Biota Neotropica. 15(1): e20140079. dx.doi.org/10.1590/1676-06032015007914

Resumo: Este estudo objetivou o levantamento taxonômico de Euastrum e Micrasterias em um ambiente tropical lêntico, visando contribuir para o conhecimento da biodiversidade e distribuição geográfica de Zygnemaphyceae. Realizado na Represa Samambaia, dez amostras foram coletadas no período seco (24/09/10 e 04/11/10) e dez no período chuvoso (06/01/11 e 02/03/11). O perifíton foi amostrado de pecíolos de plantas aquáticas (Cyperaceae) que se encontravam na região litorânea da represa. Com o levantamento florístico foram identificados 22 táxons representantes dos gêneros Euastrum (nove) e Micrasterias (13), destes, 16 são novas citações para o Estado de Goiás. Em relação à freqüência de ocorrência e ao período sazonal, 19 táxons foram enquadrados na categoria raro e três em comum, nove espécies foram registrados para o período seco, enquanto quatro somente na estação chuvosa.

Palavras-chave: desmídias, perifiton, sazonal, taxonomia, Zygnemaphyceae.

\section{Introduction}

Although of relatively discreets, algae have a great importance in the freshwater environment, both ecologically terms as in relation to human use of natural resources (Bellinger \& Sigee 2010). The number of species recognized probably underestimates the actual number of existing species, since many habitats and regions are not extensively sampled (Stevenson et al. 1996).

When algae lives with bacteria, fungi, protozoa and microcrustaceans, they form the periphyton, a complex community of microorganisms with organic or inorganic debris adhered and associated to a natural or artificial, living or dead substrate (Wetzel 1983). Thus the periphyton serves as a microcosm which occurs simultaneously in their bioderme, autotrophic and heterotrophic internal processes (Wetzel 1983). Still, periphyton is the food basis for the trophic chains because is rich in proteins, vitamins and minerals important for many organisms, as well as represents an effective participation in the recycling of various inorganic nutrients and photosynthetic production, since most of their components are algae (Wetzel 1983).
Periphytic algae are of interest because these organisms play an important role in both lotic and lentic water bodies because as primary producers (Lam \& Lei 1999), they are a protein food source and shelter for many invertebrates and fishes (Cattaneo \& Kalf 1978). And is this important and complex community that we can find the green algae belonging to the class Zygnemaphyceae and covering two orders, the Desmidiales and Zygnematales.

In Desmidiales, among four families (Gonatozygaceae, Peniaceae, Closteriaceae and Desmidiaceae) according to the classification of Mix (1972) proved by McCourt et al. (2000) using analysis of molecular biology, the Desmidiaceae family is the largest in number of genus and species. Most species of this family have a median constriction that defines the narrow isthmus, which connects the two halves of cell (Brook 1981, Coesel 1996), for example, the genus Euastrum and Micrasterias target in this study. Another point, is that the species of this order are found in oligomesotrophic aquatic environments (Coesel 1996, Gerrath 2003).

Taxonomic papers that specifically address the genus Euastrum and Micrasterias are more common to the State of 
Paraná (Moresco et al. 2009, Felisberto \& Rodrigues 2011), Rio de Janeiro (Sophia 1989), São Paulo (Bicudo \& Sormus 1982, Sormus \& Bicudo 1997), Bahia (Oliveira et al. 2009, Oliveira et al. 2011) and Amazonas (Martins 1986, Melo et al. 2009). In Goiás, Felisberto \& Rodrigues (2002) have studied both genus with the periphyton of Corumbá Reservoir.

This study aims to conduct a taxonomic survey of the species of genus Euastrum and Micrasterias of periphyton in two periods (dry and rainy) in the Samambaia Reservoir. In this way, we hope contribute to the knowledge in terms of biodiversity and new records for the Midwest and consequently to Brazil.

\section{Material and methods}

The study area $\left(16^{\circ} 35^{\prime} \mathrm{S}, 49^{\circ} 16^{\prime} \mathrm{W}\right.$, Figure 1$)$ is located in Campus II of the Federal University of Goiás in Goiânia-GO, Central West region of Brazil.

The Samambaia Reservoir was constructed in 1972 by damming the stream Samambaia (Brandão \& Kravchenko 1997), it has an average depth of $3.5 \mathrm{~m}$ and was characterized as an environment oligo to mesotrophic (Nogueira 1999). This reservoir has been built to the purpose of fish farming experiments of Federal University of Goiás (UFG) and later went on to supply the entire university campus through the company of Goiás Sanitation S/A (Saneago), although there are significant point sources and diffuse of pollutants (Nogueira 1999).

Sampling stations were abbreviated as $\mathrm{P} 1=$ the island, $\mathrm{P} 2=$ near the Saneago house, P3 = next to the nascent, P4 = beside of the forest and P5 = bar near the road to the dam.

The characterization of drought and rain was based on climatological daily data rainfall obtained through newsletters from the Evapopluviometric Station of Goiânia, located in the School of Agronomy and Food Engineering, UFG, distant about $600 \mathrm{~m}$ of the study area. The climate in the study area is considered as tropical by according to Köppen classification (Peel et al. 2007).

Periphyton was collected from stems of aquatic plants (Cyperaceae) that were in the marginal area of the reservoir (Three petioles per sample point), five sampling points in the study area. Twenty samples were collected, ten in the dry season $(24 / 09 / 10$ and $04 / 11 / 10)$ and ten in the rainy season $(06 / 01 / 11$ and $02 / 03 / 11)$.

The periphytic substrate material was removed with the aid of a razor blade followed by distilled water jets. After scraping, the material was transferred to vials, preserved and fixed with Transeau solution (Bicudo \& Menezes 2006).

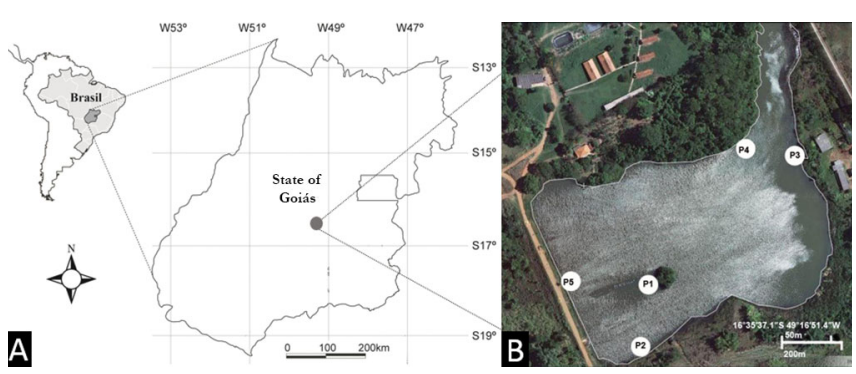

Figure 1. Location map of the Samambaia Reservoir (A). Sampling stations of the Samambaia Reservoir (B): P1 to P5. Source: Souza et al. (2014).
The samples are deposited in the herbarium collection of the Federal University of Goiás, Goiânia-GO under the numbering 47324-47349.

The samples were analyzed between slide and cover slip in the preparation of 10 temporary blades per sample. The capture images of subjects was processed with the aid of the optical microscope ZEISS brand (model Axioskop 40) and a digital camera coupled by the optical system of the microscope.

Identification of taxa was made by the morphological and morphometric characteristics of the cells, which were obtained by the optical microscope at the increase of 40x and 100x, and consultation to the specialized literature base, including articles, reviews and monographs. It was observed, when possible, the three views necessary for taxonomic identification of the desmids: frontal, lateral and apical. For the taxonomic classification, it was followed the recommendation of Bicudo \& Menezes (2006).

The frequency of occurrence, in percent, was calculated considering the presence and absence of the taxon in the sampling stations and divided by the total number of taxa sampled. The categories used were: Rare $(\leq 10 \%)$, Common $(>10 \% \leq 30 \%)$ and Constant ( $>30 \%$ ), adapted from Guille (1970).

\section{Results and discussion}

Finalized the taxonomic survey of the genus studied, a total of 22 taxa of Euastrum (9) and Micrasterias (13) were identified.

\section{Euastrum Ehrenberg ex Ralfs 1848}

Cells isolated, oval, trapezoid to quadrilateral, usually longer than broad, deep median incision; semicells usually 3lobed, two lateral lobes, the polar generally have an apical notch and is more deeply incised around the margin, smooth cell wall; semicell with a relatively narrow isthmus (Bicudo \& Menezes 2006).

Euastrum abruptum Nordstedt, Vid. Medd. Naturh. Foren. Kjöbenhavn, III (14/15): 217. Pl. 2, fig. 3. 1869 (1870). (Figure 2a)

Cell longer than wide ( $71 \times 45 \mu \mathrm{m}$; isthmus: $13 \mu \mathrm{m})$; deep median constriction, fully enclosed central sine, trapezoidal semicell, slender, 3-lobed, interlobar incisions U-shaped open, deep; lateral lobes of an semicell separated by semi-quadrangular incisions of the lateral lobes of the other semicell, deep; polar lobe with oval sinus, margins of lobes with a closely wavy process.

Geographical distribution in the State of Goiás: Förster (1964, 1969).

Material selected: BRAZIL. GOIÁS: Goiânia, Samambaia Reservoir P2, 01/III/2011, Felisberto et al. 18 (UFG 47341).

Among the taxa identified, Euastrum abruptum can be easily confused with Euastrum evolutum. This is because they share a slight resemblance in the form of their semicell, which are trapezoidal. When carefully observed, they can be distinguished by the length of their cells, Euastrum abruptum is larger and thinner than Euastrum evolutum. The lateral lobes of a semicell are separated by semi-quadrangular incisions of lateral lobes of the other semicell, and the polar lobe has an oval sinus, characteristics there are not analyzed in Euastrum evolutum, in which the lateral lobes do not have incisions that separate them of the lateral lobe of the other semicell, and the lobe apex has a V-shaped sinus, instead of oval. 


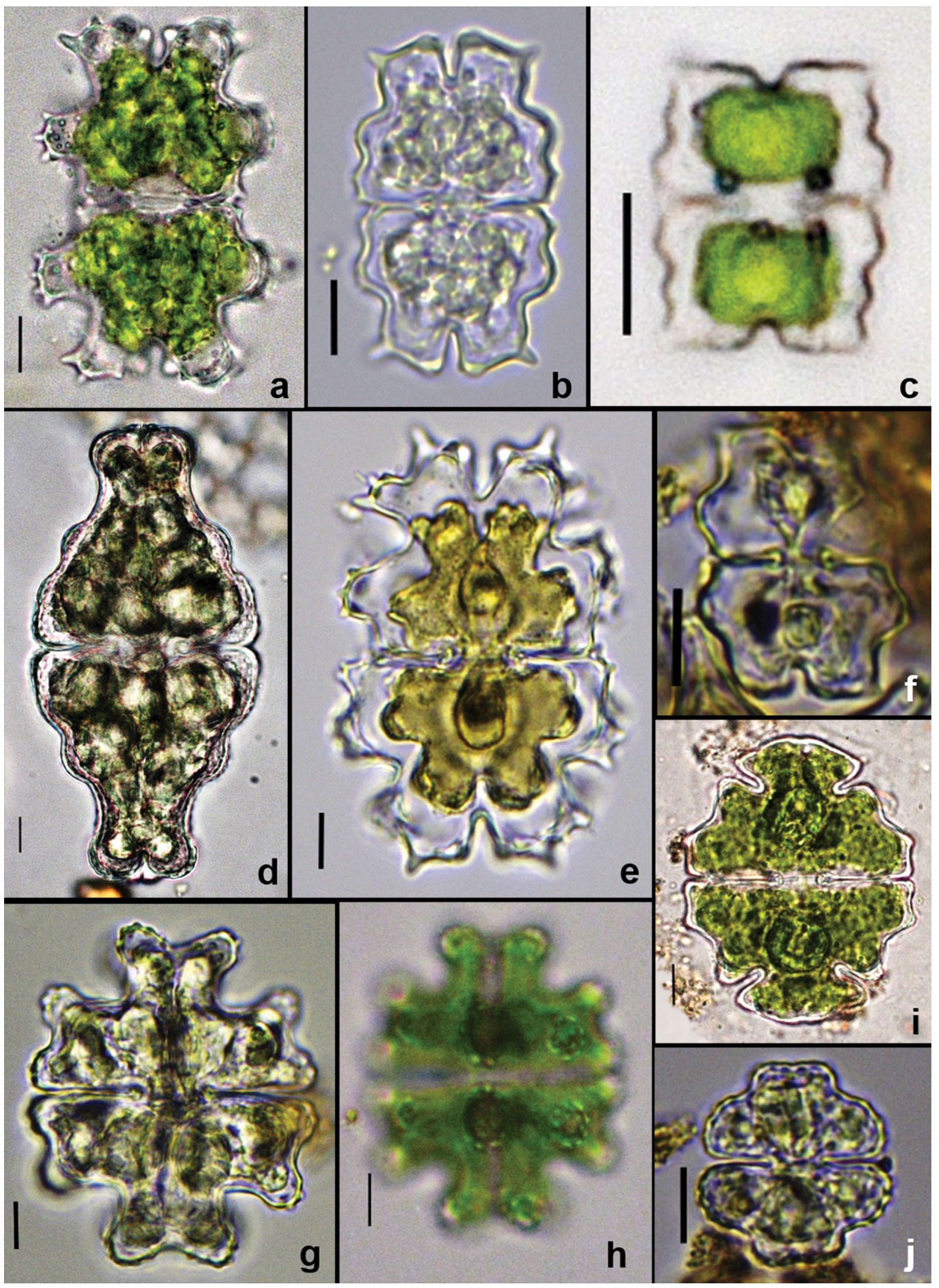

Figure 2: Euastrum of the Samambaia Reservoir. Fig. 2a. Euastrum abruptum Nordstedt. Fig. 2b. E. bidentatum Nägeli. Fig. 2c. E. denticulatum Gay. Fig. 2d. E. didelta (Turpin) Ralfs var. quadriceps (Nordstedt) Krieger. Fig. 2e. E. evolutum Scott \& Croasdale. Fig. 2f. E. gayanum De Toni var. angulatum Krieger. Fig. 2g and 2h. E. gemmatum (Brébisson) Brébisson ex Ralfs var. gemmatum (Fig. 2h, focus on ornamental wall). Fig. 2i. E. subintegrum Nordstedt var. brasiliense Grönblad. Fig. 2j. E. subornatum West \& Westvar. brasiliense Borge. Scale bar $=10 \mu \mathrm{m}$. 
Euastrum bidentatum Nägeli, Einzelliger Algen, 1849: 122, pl. 7 D: figs 1a-f. (Figure 2b)

Cell longer than wide (31-34 x 19-21 $\mu \mathrm{m}$; isthmus: 4-5 $\mu \mathrm{m})$; deep median constriction, almost completely closed, slightly open at the ends; semi-elliptical semicell, 3-lobed, shallow interlobar incisions; lateral lobes ends with apex with slight indentations; polar lobe with deep V-shaped sinus; angular margins of the polar lobe with a closely wavy process.

Geographical distribution in the State of Goiás: First quote of species occurrence in the Goiás State.

Material selected: BRAZIL. GOIÁS: Goiânia, Samambaia Reservoir P1, 24/IX/2010, Felisberto et al. 1 (UFG 47324); P2, 24/IX/2010, Felisberto et al. 2 (UFG 47325); P4, 24/IX/2010, Felisberto et al. 4 (UFG 47327); P2, 04/XI/2010, Felisberto et al. 8 (UFG 47331); P5, 01/III/2011, Felisberto et al. 21 (UFG 47344).

Euastrum bidentatum shows a deep incision at the apex of each of its semicells and is adorned with small projections, almost thorny, which are arranged in particular, at the contours areas of the semicell curvatures.

Euastrum denticulatum Gay, Bull. Soc. Bot. France 31: 335. 1884. (Figure 2c)

Cell slightly longer than wide (22-29 x 19-22 $\mu \mathrm{m}$; isthmus: 5-6 $\mu \mathrm{m})$; deep median constriction, almost completely enclosed, slightly open at the ends; semicell semi-quadrangular, 3-lobed, interlobar incisions shallow; lateral lobes ends with a convex apex; polar lobe with a semioval deep sinus; straight apical margin of the polar lobe, and angular margins with small processes.

Geographical distribution in the State of Goiás: Felisberto \& Rodrigues (2002).

Material selected: BRAZIL. GOIÁS: Goiânia, Samambaia Reservoir P1, 04/XI/2010, Felisberto et al. 7 (UFG 47330); P3, 01/III/2011, Felisberto et al. 19 (UFG 47342); P5, 01/III/2011, Felisberto et al. 21 (UFG 47344).

The taxa Euastrum denticulatum and Euastrum gayanum var. angulatum have cells with sizes very close and your frontal lobes exhibit slightly convex sum its thus, can easily be confused when they observed more closely. However, the semicell of $E$. denticulatum is semi-quadrangular, unlike E. gayanum var. angulatum, whose semicell is semiretangular, and the sine is fully enclosed in E. gayanum var. angulatum, whereas in E. denticulatum is slightly open at the edges. Still, the polar lobe has apical margin straight in E. denticulatum, while in E. gayanum var. angulatum is slightly wavy.

Euastrum didelta (Turpin) Ralfs var. quadriceps (Nordstedt) Willi Krieger in Kolkwitz, Rabenh. Krypt. -Fl., ed. 2. 13(1): 520; pl. 67, fig. 8-10. 1937. (Figure 2d)

Cell much longer than wide $(112 \times 57 \mu \mathrm{m}$; isthmus: $16 \mu \mathrm{m})$; deep median constriction, almost completely enclosed, slightly open at the ends; trapezoidal semicell, almost indistinct lobes, interlobar incisions flatly concave; lateral lobes ends with a slight indentations at the apices; polar lobe with truncated apex, forming a lip; thick cell wall and adorned with punctuations.

Geographical distribution in the State of Goiás: First citation of occurrence of species in the Goiás State.

Material selected: BRAZIL. GOIÁS: Goiânia, Samambaia Reservoir P5, 24/IX/2010, Felisberto et al. 5 (UFG 47328).

Euastrum didelta var. quadriceps differs from the typical variety by having three protrusions well marked just above the isthmus and coarse scores in the cell wall.
Euastrum evolutum (Nordstedt) West \& G.S.West var. evolutum, Trans. Linn. Soc. London, Bot. 5: 243, 1896. (Figure 2e)

Cell longer than wide (49-60 x 30-38 $\mu \mathrm{m}$; isthmus: 7-12 $\mu \mathrm{m})$; deep median constriction, almost completely enclosed, slightly open at the ends; trapezoidal semicell, robust, 3-lobed, interlobar deep incisions, U-shaped open; lateral and polar lobes with deep recesses in the apex; polar lobe with a deep sinus, V-shaped; margins of lobes with many closely corrugated processes.

Geographical distribution in the State of Goiás: First citation of occurrence of species in the Goiás State.

Material selected: BRAZIL. GOIÁS: Goiânia, Samambaia Reservoir P1, 04/XI/2010, Felisberto et al. 7 (UFG 47330); P2, 04/XI/2010, Felisberto et al. 8 (UFG 47331); P3, 04/XI/2010, Felisberto et al. 9 (UFG 47332); P4, 04/XI/2010, Felisberto et al. 10 (UFG 47333); P1, 06/I/2011, Felisberto et al. 12 (UFG 47335); P2, 06/I/2011, Felisberto et al. 13 (UFG 47336): P3, 06/ I/2011, Felisberto et al. 14 (UFG 47337); P2, 01/III/2011, Felisberto et al. 18 (UFG 47341); P5, 01/III/2011, Felisberto et al. 21 (UFG 47344).

Euastrum gayanum de Toni var. angulatum Krieger, Desm. Ber. Deutsch. Bot. Ges. 63 (2): 37, fig. 3. 1950. (Figure 2f)

Cell slightly longer than wide (20-30 x 16-25 $\mu \mathrm{m}$; isthmus: 3 ? $4 \mu \mathrm{m}$ ); deep median constriction, fully enclosed; semiretangular semicell, 3-lobed, interlobar incisions very shallow; lateral lobes with slightly convex apices; polar lobe with flatly semioval sinus; apical margin of the polar lobe slightly wavy and angular margins with small processes.

Geographical distribution in the State of Goiás: First citation of occurrence of species in the Goiás State.

Material selected: BRAZIL. GOIÁS: Goiânia, Samambaia Reservoir P3, 24/IX/2010, Felisberto et al. 3 (UFG 47326).

Euastrum gemmatum (Brébisson) Brébisson ex Ralfs var. gemmatum, Brit. Desmid.: 87; pl. 14, fig. 4. 1848. (Figure 2g-h)

Cell longer than wide (51-54 x 41-47 $\mu \mathrm{m}$; isthmus: $10-13 \mu \mathrm{m})$; deep median constriction, almost completely closed, slightly open at ends; semicircle semicell, 3-lobed, interlobar deep incisions, U-shaped open; lateral and polar lobes with deep recesses in the apices; apical margins of the lobes convex; semicell with 3 circular tumescence quite evident in the region between the frontal lobes; the lateral largest than the side, prominent, ornamented with 2 rings of rounded granules; ornamented wall with granules.

Material selected: BRAZIL. GOIÁS: Goiânia, Samambaia Reservoir P3, 24/IX/2010, Felisberto et al. 3 (UFG 47326); P4, 24/IX/2010, Felisberto et al. 4 (UFG 47327); P4, 04/IX/ 2010, Felisberto et al. 10 (UFG 47333); P5, 04/IX/2010, Felisberto et al. 11 (UFG 47334); P2, 06/I/2011, Felisberto et al. 13 (UFG 47336); P2, 01/III/2011, Felisberto et al. 18 (UFG 47341).

Euastrum subintegrum Nordstedt var. brasiliense Grönblad, Acta Soc. Sci. Fenn. 2(6): 14; pl. 4, fig. 69, 70. 1945. (Figure 2i)

Cell longer than wide (60-87 x 47-65 $\mu \mathrm{m}$; isthmus: 9-14 $\mu \mathrm{m})$; deep median constriction, almost completely enclosed, slightly open at the ends; trapezoidal semicell, 3-lobed, interlobar incisions deep lanceolate; lateral lobes with deep recesses in the apices; convex polar lobe; rounded angular margins; semicell with tumescence circular lateral, prominent, ornamented with 2 rings of rounded granules; smooth cell wall.

Geographical distribution in the State of Goiás: First citation of occurrence of species in the Goiás State.

Material selected: BRAZIL. GOIÁS: Goiânia, Samambaia Reservoir Samambaia P3, 06/I/2011, Felisberto et al. 9 (UFG 
47332); P4, 06/I/2011, Felisberto et al. 10 (UFG 47333); P2, 01/III/2011, Felisberto et al. 18 (UFG 47341).

Euastrum subintegrum var. brasiliense is differentiated from the others taxa found in the Samambaia Reservoir, by having a convex polar lobe with rounded angles and especially for presenting the semicell face with only a single central tumescence, prominent and ornate with two rings of rounded granules, which also differentiate from Euastrum gemmatum var. monocylum that displays three tumescences.

Euastrum subornatum West \& G.S.West var. brasiliense Borge, Ark. Bot. 1: 114; pl. 5, fig. 6. 1903. (Figure 2j)

Cell slightly longer than wide (39-49 x 35-44 $\mu \mathrm{m}$; isthmus: 10-12 $\mu \mathrm{m}$ ); deep median constriction, central linear sine, fully open, opening to the isthmus; trapezoidal semicell, 3-lobed, interlobar incisions flatly concave; lateral lobes rounded; slightly truncated polar lobe; semicell with tumescence in the midline of the lateral lobes formed by a single ring of granules; cell wall ornate with granules.

Geographical distribution in the State of Goiás: First citation of occurrence of species in the Goiás State.

Material selected: BRAZIL. GOIÁS: Goiânia, Samambaia Reservoir P4, 04/IX/2010, Felisberto et al. 10 (UFG 47333); P1, 01/III/2011, Felisberto et al. 17 (UFG 47340).

The slightly truncated polar lobe, cell with linear and fully open sinus and the tumescence of semicell face with only a single ring of granules, distinguish it from the others taxa sampled.

Micrasterias Agardh ex Ralfs 1848

Isolated cells to pseudofilamentous (Micrasterias foliacea), circular to elliptical, deep median constriction; semicells 3-5-lobed, with four deep incisions in the axis of the cell; polar lobe lengthy to expanded, never divided into lobules, unlike the lateral which have divisions into lobules; cell wall smooth to ornamented (Bicudo \& Menezes 2006).

Micrasterias abrupta West \& G.S.West, Trans. Linn. Soc. London, Bot. 5: 241, pl. 14, figs. 13-16, 1896. (Figure 3a)

Cell as wide as long (51-54 x 49-52 $\mu \mathrm{m}$; isthmus: 10-12 $\mu \mathrm{m})$; deep median constriction, sine closed near the central isthmus and open at the ends; semioval semicell, 5-lobed; interlobular incisions basally lanceolate, open, slight between the lateral lobes and deep between the polar lobes and lateral; lateral lobes with two bifurcations, bidenticulate apices; polar lobe with an inverted deltoid, with bidenticulate angles, apical margin straight; polar lobe greater than the lateral.

Geographical distribution in the State of Goiás: First citation of occurrence of species in the Goiás State.

Material selected: BRAZIL. GOIÁS: Goiânia, Samambaia Reservoir P4, 24/IX/2010, Felisberto et al. 4 (UFG 47327); P5, 24/IX/2010, Felisberto et al. 5 (UFG 47328); P4, 04/IX/2010, Felisberto et al. 10 (UFG 47333).

Micrasterias abrupta and Micrasterias truncata var. pusilla are visually similar, cells are as wide as long, have a central sine closed near the isthmus and is open at the ends, but the semicell of Micrasterias abrupta have a semioval format and its polar lobe has an apical straight edge with bidenticulate angles, in contrast the Micrasterias truncata var. pusilla have its semicell with semi-orbicular shape and polar lobe with a convex apical margin and acuminate angles.

Micrasterias borgei Krieger In Rabenhorst, KryptogamenFl. Deutschl. 13(2):86, pl. 128, fig. 1-4. 1939. (Figure 3b)

Cell longer than wide (225 x $206 \mu \mathrm{m}$; isthmus: $32-40 \mu \mathrm{m})$; deep median constriction, center sine closed, slightly open at the ends; semi-elliptical semicell, 5-lobed, robust lobes; polar lobe with incision opened a little more than half of its length; incisions between the lateral lobes opened and deep, $U$ or V-shaped; lateral lobes with consecutive bifurcations till the apex, slightly curved denticles polar lobe with a deep sinus, apex divided into two bidenticulate divergent lobes, central denticles slenderly facing the sinus; polar lobe greater and more robust than the laterals.

Geographical distribution in the State of Goiás: First citation of occurrence of species in the Goiás State.

Material selected: BRAZIL. GOIÁS: Goiânia, Samambaia Reservoir P5, 06/I/2011, Felisberto et al. 16 (UFG 47339); P2, 01/III/2011, Felisberto et al. 18 (UFG 47341).

Micrasterias foliacea Bailey ex Ralfs var. foliacea Brit. Desmidieae 210, pl. 35, fig. 3. 1848. (Figure 3c)

Cell wider than long (59-69 x $90 \mu \mathrm{m}$; isthmus: $14-15 \mu \mathrm{m})$; cells forming pseudofilaments that cling to each other by the poles; deep median constriction, central sine open; semirectangular semicell, 5-lobed; open and deep interlobular incisions, misshapen; lateral lobes asymmetrically bifurcate, only one lobule near the polar lobe have an integrate apex; apical margins of the lateral lobes bidenticulate with an openly deltoid sinus; polar lobe with deep incision, semi quadratic, chamfered angles; polar lobe slightly bigger than the lateral lobes.

Geographical distribution in the State of Goiás: First citation of occurrence of species in the Goiás State.

Material selected: BRAZIL. GOIÁS: Goiânia, Samambaia Reservoir P3, 04/XI/2010, Felisberto et al. 9 (UFG 47332); P4, 06/I/2011, Felisberto et al. 15 (UFG 47338); P2, 01/III/2011, Felisberto et al. 18 (UFG 47341).

Micrasterias foliacea is easily distinguishable from the others taxa belonging to the Micrasterias genus, by their cells form pseudofilaments, which adhere to each other through their poles. An interesting feature is that only one lobule of the lateral lobes have an integrate apex, and the same is close to the polar lobe with chamfered angles.

Micrasterias furcata C. Agardh ex Ralfs, Desmidieae 73, pl. 9, fig. 2. 1848. (Figure 3d-f)

Cell longer than wide (126-156 x 103-124 $\mu \mathrm{m}$; isthmus: 18 $19 \mu \mathrm{m})$; deep median constriction, central sine closed near the isthmus and open at the ends; semi-elliptical semicell, 5-lobed, robust lobes; polar lobe with open incision a little more than half of its length; incisions between the lateral lobes opened and deep, U or V-shaped; lateral lobes with consecutive bifurcations, polar lobe with semicircular sinus, apex divided into two divergent lobules bidenticulate, slightly curved denticles; polar lobe bigger and more robust than the lateral lobes.

Geographical distribution in the State of Goiás: First citation of occurrence of species in the Goiás State.

Material selected: BRAZIL. GOIÁS: Goiânia, Samambaia Reservoir P5, 24/IX/2010, Felisberto et al. 5 (UFG 47328); P1, 04/XI/2010, Felisberto et al. 7 (UFG 47330); P4, 04/XI/2010, Felisberto et al. 10 (UFG 47333); P1, 06/I/2011, Felisberto et al. 12 (UFG 47335); P2, 06/I/2011, Felisberto et al. 13 (UFG 47336); P1, 01/III/2011, Felisberto et al. 17 (UFG 47340); P2, 01/III/2011, Felisberto et al. 18 (UFG 47341); P4, 01/III/2011, Felisberto et al. 20 (UFG 47343); P5, 01/III/2011, Felisberto et al. 21 (UFG 47344).

Individuals of Micrasterias furcata that were analyzed for the Samambaia Reservoir showed some differences when compared. There was morphological variation in incisions between lobes and between the lobules, some exhibited the 


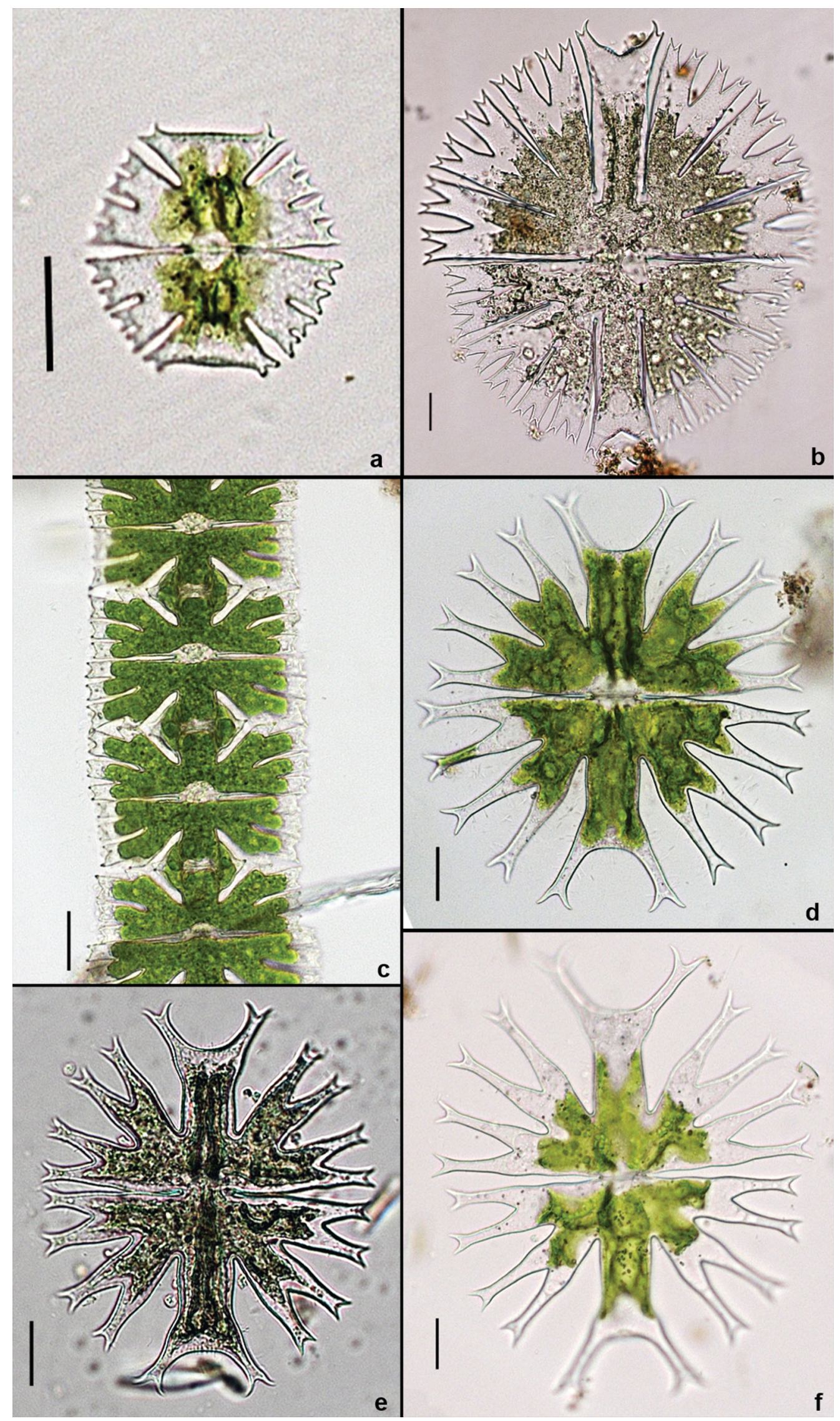

Figure 3: Micrasterias of the Samambaia Reservoir. Fig. 3a. Micrasterias abrupta West \& West. Fig. 3b. M. borgei Krieger. Fig. 3c. M. foliacea Bailey ex Ralfs. Fig. 3d, 3e and 3f. M. furcata Agardh ex Ralfs (Fig. 3e and 3f.: morphological expressions of the typical variety). Scale bar $=10 \mu \mathrm{m}$. 
polar lobe longest and others shorter and wider. Lateral lobes sometimes were thin, but in some cases, the lobes were more robust.

Micrasterias laticeps Nordstedt var. laticeps, Vidensk. Medd. Naturh. Foren. 1869 (14-15): 220. 1870. (Figure 4a)

Cell wider than long (109-161 x 127-190 $\mu \mathrm{m}$; isthmus: 21-42 $\mu \mathrm{m}$ ); deep median constriction, central sine closed near the isthmus and then opened; semi-orbicular semicell, 3-lobed; interlobular incisions opened and deep, V-shaped; apices of the lateral and polar lobes facing to the opening of the sine, polar lobes bigger than the lateral lobes, angles of the polar lobe acuminated and lateral lobes bidenticulate.

Geographical distribution in the State of Goiás: Förster (1964).

Material selected: BRAZIL. GOIÁS: Goiânia, Samambaia Reservoir P3, 24/IX/2010, Felisberto et al. 3 (UFG 47326); P4, 24/IX/2010, Felisberto et al. 4 (UFG 47327); P5, 24/IX/2010, Felisberto et al. 5 (UFG 47328); P3, 04/XI/2010, Felisberto et al. 9 (UFG 47332).

Micrasterias laticeps Nordstedt var. acuminata Krieger, In Rabenhorst, Kryptogamen-Fl. Deutschl. 13(2):14, pl.98, fig. 2. 1939. (Figure 4b)

Cell wider than long (60-84 x 79-107 $\mu \mathrm{m}$; isthmus: $14-16$ $\mu \mathrm{m})$; deep median constriction, center sine closed near the isthmus and then opened; semi-orbicular semicell, 3-lobed; open and deep interlobular incisions, V-shaped; apices of the lateral and polar lobes facing to the opening of the sine, polar lobe bigger than the lateral lobes, lobes with acuminate angles.

Geographical distribution in the State of Goiás: Förster (1964).

Material selected: BRAZIL. GOIÁS: Goiânia, Samambaia Reservoir P5, 04/XI/2010, Felisberto et al. 11 (UFG 47334).

Micrasterias laticeps var. acuminata resembles with its typical variety, because both have the semicell with semiorbicular format and the apices of the lateral and polar lobes are facing to the opening of the sine. But the angles of the lobes in Micrasterias laticeps var. acuminata are all acuminated, which differentiates it from your typical variety that only have the angles of the polar lobe acuminated, having the lateral lobes with angles bidenticulate.

Micrasterias mahabuleshwarensis J. Hobson var. mahabuleshwarensis Quart. Jour. Microsc. Sci. 1863: 169, fig. p.168. 1863. (Figure 4c-d)

Cell longer than wide ( $165 \times 142 \mu \mathrm{m}$; isthmus: $26 \mu \mathrm{m})$; deep median constriction, fully open median incision, triangular, 5-lobed semicell; semi-rectangular incisions between the polar lobe and the lateral, open and deep; lateral lobes with pyramidal sinus, divergent lobules with entire apices; polar lobe with divergent processes with entire apices, apical margin of the polar lobe is straight; polar lobe of the same size as the sides; serrated cell margin.

Geographical distribution in the State of Goiás: First citation of occurrence of species in the Goiás State.

Material selected: BRAZIL. GOIÁS: Goiânia, Samambaia Reservoir P5, 24/IX/2010, Felisberto et al. 5 (UFG 47328).

Sampled taxa of the genus Micrasterias for the Samambaia Reservoir, Micrasterias mahabuleshwarensis is the one cell that displays serrated margin. This taxon also shows the polar lobe sharply projected beyond the side lobes and intra-marginal spines throughout the cell.

Micrasterias pinnatifida (Kützing) ex Ralfs, Brit. Desm., 77. Pl. 10, fig. 3. 1848. (Figure 4e)
Cell wider than long (51-66 x 59-66 $\mu \mathrm{m}$; isthmus: 11-18 $\mu \mathrm{m})$; deep median constriction, center sine closed near the isthmus and then open; trapezoidal semicell, 3-lobed, interlobar and deep incisions open, U-shaped; polar lobes and lateral with bidenticulate angles, polar lobes smaller than the lateral lobes.

Geographical distribution in the State of Goiás: First citation of occurrence of species in the Goiás State.

Material selected: BRAZIL. GOIÁS: Goiânia, Samambaia Reservoir P1, 24/IX/2010, Felisberto et al. 1 (UFG 47324); P3, 24/IX/2010, Felisberto et al. 3 (UFG 47326); P4, 24/IX/2010, Felisberto et al. 4 (UFG 47327); P5, 24/IX/2010, Felisberto et al. 5 (UFG 47328); P1, 04/XI/2010, Felisberto et al. 7 (UFG 47330); P2, 04/XI/2010, Felisberto et al. 8 (UFG 4731); P3, 04/ $\mathrm{XI} / 2010$, Felisberto et al. 9 (UFG 47332); P4, 04/XI/2010, Felisberto et al. 10 (UFG 47333); P5, 04/XI/2010, Felisberto et al. 11 (UFG 47334); P1, 06/I/2011, Felisberto et al. 12 (UFG 47335); P1, 01/III/2011, Felisberto et al. 17 (UFG 47340); P2, 01/III/2011, Felisberto et al. 18 (UFG 47341); P5, 01/III/2011, Felisberto et al. 21 (UFG 47344).

Micrasterias radiosa Ralfs var. radiosa Brit. Desm: 72. pl. 8, fig. 3, 1848. (Figure 4f)

Cell as long as wide (111-126 x 105-129 $\mu \mathrm{m}$; isthmus: $13-16$ $\mu \mathrm{m})$; deep median constriction, central sine almost entirely closed, open only at the ends; semicircular semicell, 5-lobed; polar lobe with linear incision until near of the isthmus; misshapen incisions, slightly open and deep between the polar lobes; lateral lobes with consecutive bifurcations; polar lobe with sinus V-shaped, apex divided into two divergent lobules bidenticulate, polar lobe with the same size as the lateral lobes.

Geographical distribution in the State of Goiás: First citation of occurrence of species in the Goiás State.

Material selected: BRAZIL. GOIÁS: Goiânia, Samambaia Reservoir P1, 24/IX/2010, Felisberto et al. 1 (UFG 47324); P4, 04/XI/2010, Felisberto et al. 10 (UFG 47333); P5, 04/XI/2010, Felisberto et al. 11 (UFG 47334).

Micrasterias radiosa Ralfs var. elegantior (G.S.West) Croasdale In Prescott et al. Syn. N. Amer. Desm. 2(2): 181, pl. 132, fig. 2-4. 1977. (Figure 5a)

Cell as long as wide (145-150 x 148-149 $\mu \mathrm{m}$; isthmus: 17-20 $\mu \mathrm{m})$; deep median constriction, central sine fully opened; semicircular semicell, 5-lobed, slender lobes; polar lobe with open incision until near the isthmus; misshapen incisions, open and deep between the lateral lobes; lateral lobes with consecutive bifurcations, polar lobe with deltoid sinus, apex divided into two divergent lobules, bidenticulate; polar lobe with the same size lateral lobes.

Geographical distribution in the State of Goiás: First citation of occurrence of species in the Goiás State.

Material selected: BRAZIL. GOIÁS: Goiânia, Samambaia Reservoir P4, 04/XI/2010, Felisberto et al. 10 (UFG 47333).

Three taxa within the genus Micrasterias are very similar, Micrasterias radiosa var. elegantior, Micrasterias radiosa var. radiosa and Micrasterias radiosa var. ornata, having cells as wide as long and 5-lobed. In $M$. radiosa var. elegantior and $M$. radiosa var. radiosa the semicell have semicircular shape, already in $M$. radiosa var. ornata, the semicell displays the semi-orbicular format, lobes are more robust, when compared with the others two, and their cell wall is studded with large thorns, feature that specifies like ornata.

Micrasterias radiosa Ralfs var. ornata Nordstedt, Vidensk. Meddrdansk naturh. Foren. (14-15): 223, pl. 2, fig. 11. 1870. (Figure 5b-c) 


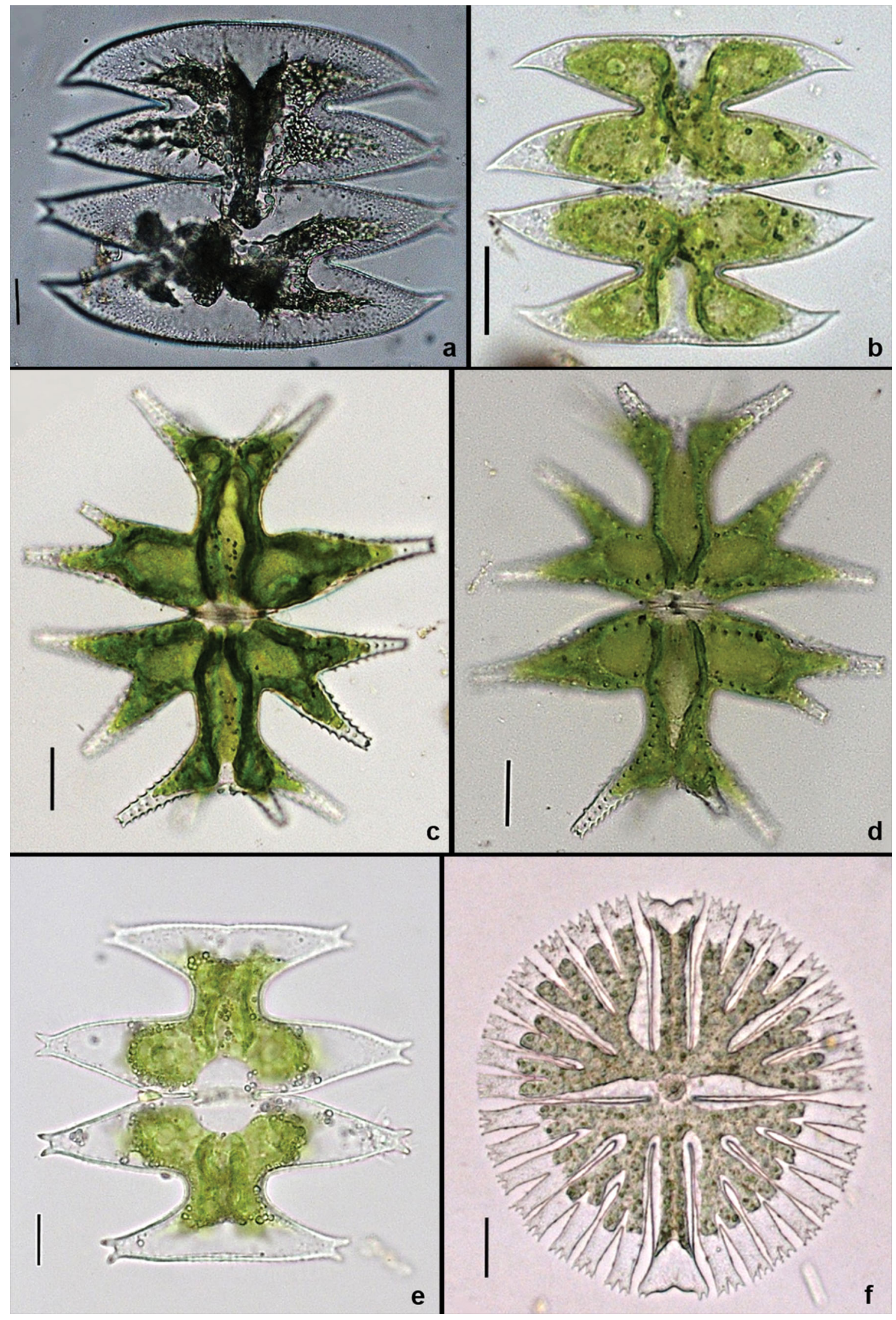

Figure 4: Micrasterias of the Samambaia Reservoir. Fig. 4a. Micrasterias laticeps Nordstedt var. laticeps. Fig. 4b. M. laticeps Nordstedt var. acuminata Krieger. Fig. 4c and 4d. M. mahabuleshwarensis J. Hobson var. mahabuleshwarensis (Fig. 4d.: focus on ornamentation of the cell wall). Fig. 4e. Micrasterias pinnatifida (Kützing) Ralfs. Fig. 4f. M. radiosa Ralfs var. radiosa. Scale bar $=10 \mu \mathrm{m}$. 

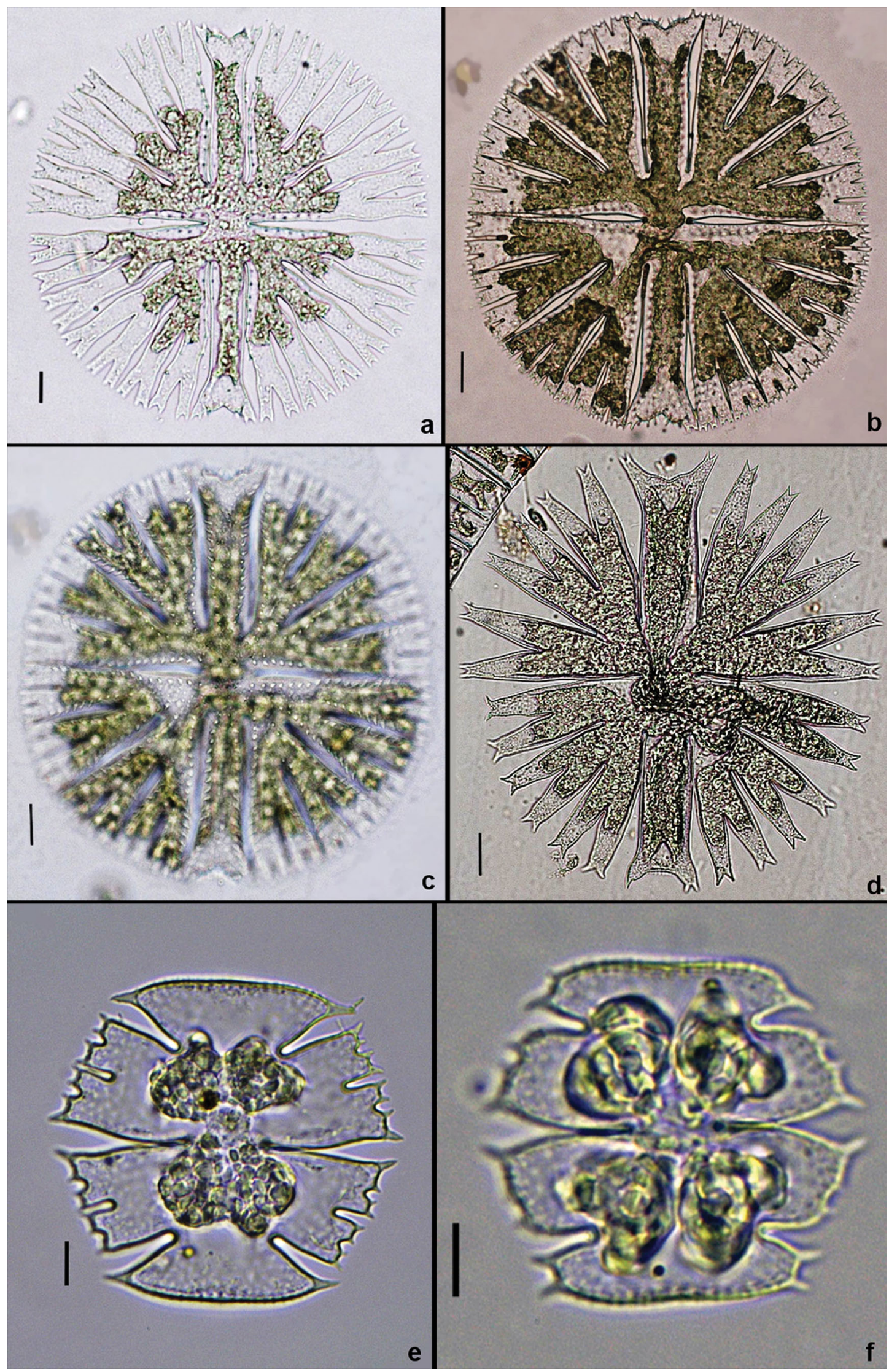

Figure 5: Micrasterias of the Samambaia Reservoir. Fig. 5a. M. radiosa Ralfs var. elegantior (G. S. West) Croasdale. Fig. 5b and 5c. M. radiosa Ralfs var. ornata Nordstedt (Fig. 5c: focus on ornamentation of the cell wall). Fig. 5d. M. torreyi Bailey ex Ralfs var. nordstedtiana (Hieronymus) Schmidle. Fig. 5e and 5f. M. truncata (Corda) Brébisson ex Ralfs var. pusilla G. S. West (Fig. 5f.: morphological expression). Scale bar $=10 \mu \mathrm{m}$. 
Table 1. Frequency of occurrence of the species found in the sampling points of the Samambaia Reservoir in both study periods (C: rain, S: dry, SC: dry and rain, *: absence of species, R: rare, Cm: common and Cs: constant). Freq. $=$ Frequency in $\%$.

\begin{tabular}{|c|c|c|c|c|c|c|}
\hline Taxa & $\mathbf{P 1}$ & $\mathbf{P 2}$ & $\mathbf{P 3}$ & P4 & P5 & Freq. \\
\hline Euastrum abruptum Nordstedt & $*$ & $\mathrm{C}$ & * & $*$ & * & $1 \mathrm{R}$ \\
\hline E. bidentatum Nägeli & $\mathrm{S}$ & $\mathrm{S}$ & * & $\mathrm{S}$ & $\mathrm{C}$ & $5 \mathrm{R}$ \\
\hline E. denticulatum Gay & $\mathrm{S}$ & * & $\mathrm{C}$ & * & $\mathrm{C}$ & $3 \mathrm{R}$ \\
\hline E. didelta (Turpin) Ralfs var. quadriceps (Nordstedt) Krieger & $*$ & $*$ & * & $*$ & $\mathrm{~S}$ & $1 \mathrm{R}$ \\
\hline E. evolutum (Nordstedt) West \& G.S.West var. evolutum & $\mathrm{SC}$ & $\mathrm{SC}$ & $\mathrm{SC}$ & $\mathrm{S}$ & $\mathrm{C}$ & $13 \mathrm{Cm}$ \\
\hline E. gayanum De Toni var. angulatum Krieger & $*$ & $*$ & $\mathrm{~S}$ & * & * & $1 \mathrm{R}$ \\
\hline E. gemmatum (Brébisson) Brébisson ex Ralfs var. gemmatum & $*$ & $\mathrm{C}$ & $\mathrm{S}$ & $\mathrm{S}$ & $\mathrm{S}$ & $6 \mathrm{R}$ \\
\hline E. subintegrum Nordstedt var. brasiliense Grönblad & $*$ & $\mathrm{C}$ & $\mathrm{C}$ & $\mathrm{C}$ & * & $4 \mathrm{R}$ \\
\hline E. subornatum West \& G.S.West var. brasiliense Borge & $\mathrm{C}$ & $*$ & * & S & * & $2 \mathrm{R}$ \\
\hline Micrasterias abrupta West \& G.S.West & $*$ & * & * & $\mathrm{S}$ & $\mathrm{S}$ & $3 \mathrm{R}$ \\
\hline M. borgei Krieger & $*$ & $\mathrm{C}$ & * & * & $\mathrm{C}$ & $2 \mathrm{R}$ \\
\hline Micrasterias foliacea Bailey ex Ralfs var. foliacea & $*$ & $\mathrm{C}$ & $\mathrm{S}$ & $\mathrm{C}$ & $*$ & $17 \mathrm{Cm}$ \\
\hline M. furcata C. Agardh ex Ralfs & $\mathrm{SC}$ & $\mathrm{C}$ & $*$ & $\mathrm{SC}$ & $\mathrm{SC}$ & $10 \mathrm{R}$ \\
\hline M. laticeps Nordstedt var. laticeps & $*$ & $*$ & $\mathrm{~S}$ & $\mathrm{~S}$ & $\mathrm{~S}$ & $3 \mathrm{R}$ \\
\hline M. laticeps Nordstedt var. acuminata Krieger & $*$ & $*$ & * & * & $\mathrm{S}$ & $1 \mathrm{R}$ \\
\hline Micrasterias mahabuleshwarensis J. Hobson var. mahabuleshwarensis & $*$ & $*$ & * & * & $\mathrm{S}$ & $1 \mathrm{R}$ \\
\hline M. pinnatifida (Kützing) ex Ralfs & $\mathrm{SC}$ & $\mathrm{SC}$ & $\mathrm{S}$ & $\mathrm{S}$ & $\mathrm{SC}$ & $15 \mathrm{Cm}$ \\
\hline M. radiosa Ralfs var. radiosa & $\mathrm{S}$ & * & $*$ & $\mathrm{~S}$ & $\mathrm{~S}$ & $3 \mathrm{R}$ \\
\hline M. radiosa Ralfs var. elegantior (G. S. West) Croasdale & $*$ & $*$ & * & $\mathrm{S}$ & $*$ & $2 \mathrm{R}$ \\
\hline M. radiosa Ralfs var. ornata Nordstedt & $*$ & $*$ & $\mathrm{~S}$ & $\mathrm{~S}$ & $*$ & $2 \mathrm{R}$ \\
\hline M. torreyi Bailey ex Ralfs var. nordstedtiana (Hieronymus) Schmidle & * & $\mathrm{C}$ & * & * & $*$ & $2 \mathrm{R}$ \\
\hline M. truncata (Corda) Brébisson ex Ralfs var. pusilla G. S. West & $*$ & $*$ & $\mathrm{SC}$ & $\mathrm{S}$ & $\mathrm{C}$ & $5 \mathrm{R}$ \\
\hline
\end{tabular}

Cell as long as wide (188-227 x 175-216 $\mu \mathrm{m}$; isthmus: 23-27 $\mu \mathrm{m})$; deep median constriction, central sine slightly closed, open at the ends; semi-orbicular semicell, 5-lobed, lobes robust compared to the elegantior variety; polar lobe with open incision until near the isthmus; misshapen incisions, opened and deep incisions between the lateral lobes; lateral lobes with consecutive bifurcations, polar lobe with sinus V-shaped, apex divided into two bidenticulate divergent lobules; polar lobe with the same size of the lateral lobes; cell wall ornate with big thorns.

Geographical distribution in the State of Goiás: First citation of occurrence of species in the Goiás State.

Material selected: BRAZIL. GOIÁS: Goiânia, Samambaia Reservoir P3, 04/XI/2010, Felisberto et al. 9 (UFG 47332); P4, 04/XI/2010, Felisberto et al. 10 (UFG 47333).

Micrasterias torreyi Bailey ex Ralfs var. nordstedtiana (Hieronymus) Schmidle, Bot. Jahrb. 26(1-2): 48. 1898. (Figure 5d)

Cell as long as wide ( $229 \times 220 \mu \mathrm{m}$; isthmus: $32 \mu \mathrm{m})$; deep median constriction, central sine closed near the isthmus and just slightly open at the ends; semicircular semicell, 5-lobed; robust lobes, contour rounded; polar lobe with linear incision until near the isthmus, opened in the ends; opened and deep incisions between the lateral lobes, V-shaped; lateral and polar lobes bifurcated, lobules bidenticulate, divergent lobules in polar lobe; polar lobe with the same size as the lateral lobes.

Geographical distribution in the State of Goiás: First quote of occurrence of species in the Goiás State.

Material selected: BRAZIL. GOIÁS: Goiânia, Samambaia Reservoir P2, 01/III/2011, Felisberto et al. 18 (UFG 47341).

For Brazil, the species is cited in other works, but in any of them, there is no illustration or description of the material found (Bicudo \& Sormus 1982). Therefore, we can consider this study as the first record of apparel for Micrasterias torreyi var. nordstedtiana for Goiás.
Micrasterias truncata (Corda) Brébisson ex Ralfs var. pusilla G.S. West, Mém. Soc. Neuchât. Sci. Nat. 5: 1035. pl. 22, fig. 42-43. 1914. (Figure 5e-f)

Cell as wide as long (33-53 x 33-58 $\mu \mathrm{m}$; isthmus; 11-12 $\mu \mathrm{m})$; deep median constriction, center sine closed near the isthmus and open at; semi-orbicular semicell, 5-lobed; opened interlobular incisions, basally lanceolate, slight between the lateral lobes and deep between the polar and lateral lobes; lateral lobes bifurcated, bidenticulate apices; inverted deltoid polar lobe with acuminated angles, convex apical margin of the polar lobe; polar lobe wider than the lateral lobes.

Geographical distribution in the State of Goiás: Felisberto \& Rodrigues (2002).

Material selected: BRAZIL. GOIÁS: Goiânia, Samambaia Reservoir P3, 24/IX/2010, Felisberto et al. 3 (UFG 47326); P4, 24/IX/2010, Felisberto et al. 4 (UFG 47327); P4, 04/XI/2010, Felisberto et al. 10 (UFG 47333); P1, 06/I/2011, Felisberto et al. 12 (UFG 47335); P3, 01/III/2011, Felisberto et al. 19 (UFG 47342); P5, 01/III/2011, Felisberto et al. 21 (UFG 47344).

Regarding the frequency of occurrence of taxa in the sampled points, we have noticed that most were framed in rare (19) and only three common taxa (Table 1). Regarding the presence and absence of taxa analyzed in the sampling stations, of the 22 taxa identified, 7 were recorded at point P1, 10 on points P2 and P3, with the highest number of taxa (14) the points P4 and P5. It was observed that only two taxa appeared at all points: Euastrum evolutum (Nordstedt) West \& G.S.West var. evolutum e Micrasterias pinnatifida (Kützing) ex Ralfs.

In relation to the exclusivity period, nine taxa were recorded for the dry period (Euastrum didelta var. quadriceps, E. gayanum var. angulatum, Micrasterias abrupta, M. laticeps var. laticeps, M. laticeps var. acuminata, M. mahabuleshwarensis var. mahabuleshwarensis, M. radiosa var. radiosa, M. radiosa var. elegantior and $M$. radiosa var. ornata), while four taxa 
were found only in the rainy season (Euastrum abruptum, E. subintegrum var. brasiliense, Micrasterias borgei and M. torrey var. nordstedtiana), as shown in Table 1 .

According to Miller et al. (1992), the supply of nutrients to light availability may have a strong impact on communities of algae. Thus, one possible explanation for greater richness in the dry season maybe related to increased stability of the water column and macrophytes (mainly in the marginal region) due to lack of rainfall and consequently lower values of turbidity and higher incidence of light on the body of water.

\section{References}

BELLINGER, E.G. \& SIGEE, D.C. 2010. Freshwater algae: identification and use as Bioindicators. Wiley-Blackwell, West Sussex.

BICUDO, C.E.M. 1969. Contribution to the knowledge of the State of São Paulo, Brazil (including from the State of Minas Gerais). Nova Hedwigia 17:443-549.

BICUDO, C.E.M. \& MARTINS, D.V. 1989. Desmídias (Zygnemaphyceae) de Itanagra, Estado da Bahia, Brasil. Revista Brasileira de Biologia 49:309-324.

BICUDO, C.E.M. \& MENEZES, M. 2006. Gêneros de algas de águas continentais do Brasil: chave para identificação e descrições. RiMa Editora, São Carlos.

BICUDO, C.E.M. \& SORMUS, L. 1974. Polymorphism in the desmid Micrasterias pinnatifida and its taxonomical implications. Journal of Phycology 10:274-279.

BICUDO, C.E.M. \& SORMUS, L. 1982. Desmidiofórula Paulista II: gênero Micrasterias C. Agardh ex Ralfs. Bibliotheca Phycologica 57:1-230.

BIOLO, S., SIQUEIRA, N.S. \& BUENO, N.C. 2008. Desmidiaceae (exceto Cosmarium) de um tributário do Reservatório de Itaipu, Paraná, Brasil. Hoehnea 35:309-326.

BITTENCOURT-OLIVEIRA, M.C. \& MECENAS, P.R. 1994. Ficoflórula do Rio Tibagi, Estado do Paraná, Brasil, IV: gêneros Micrasterias, Staurastrum e Xanthidium (Zygnemaphyceae). Semina 15:133-152.

BORGE, O. 1903. Die Algen der ersten Regnellschen Expedition, 2: Desmidiaceae. Arkiv för Botanik 1:71-138.

BORGE, O. 1918. Die von Dr. A. Löfgren in São Paulo gessammelten Süsswasseralgen. Arkiv för Botanik 15:1-108.

BRANDÃO, D. \& KRAVCHENKO, A. 1997. A biota do Campus Samambaia: história, situação atual e perspectivas. Editora da UFG, Goiânia, 157 p.

BROOK, A.J. 1981. The biology of desmids. Blackwell Scientific Publications, Oxford, London. $276 \mathrm{pp}$

CATTANEO, A. \& KALF, J. 1978. Seasonal changes in the epiphyte community of natural and artificial macrophytes in lake memphremagog (Que. \& VT). Hydrobiologia 60:135-144, doi: 10.1007/ BF00163179

COESEL, P.F.M. 1996. Biogeography of desmids. Hydrobiologia, 336: 41-53.

FELISBERTO, S.A. \& RODRIGUES, L. 2002. Desmidiales (exceto o gênero Cosmarium) perifíticas no reservatório de Corumbá, Goiás, Brasil. Iheringia 57:75-97.

FELISBERTO, S.A. \& RODRIGUES, L. 2005. Influência do gradiente longitudinal rio-barragem na similaridade da assembléia de Desmídias perifíticas. Revista Brasileira de Botânica 28:241-254.

FELISBERTO, S.A. \& RODRIGUES, L. 2008. Desmidiaceae, Gonatozygaceae e Mesotaeniaceae na comunidade perifítica do reservatório de Salto do Vau (Bacia do rio Iguaçu, PR). Hoehnea 35:235-254

FELISBERTO, S.A. \& RODRIGUES, L. 2011. Desmídias epifíticas do reservatório de Rosana, bacia do rio Paranapanema, Paraná/ São Paulo, Brasil: Euastrum e Micrasterias (Desmidiaceae). Revista Brasileira de Biociências 9: 206-213.
FÖRSTER, K. 1963. Desmidiaceen aus Brasilien. 1. Nord Brasilien. Revue Algologie 7:38-92.

FÖRSTER, K. 1964. Desmidiaceen aus Brasilien 2, Teil: Bahia, Goyaz. Phiuhy und Nord- Brasilien. Hydrobiologia 23:321-505, doi: 10.1007/BF00179497

FÖRSTER, K. 1969. Amazonische desmidien, 1. Amazoniana 2:5-116.

GERRATH, J.F. 2003. Conjugating green algae and desmids. In Freshwater algae of North America: ecology and classification (WEHR, J.D. \& SHEATH, R.G. eds). San Diego: Elsevier Science Academic Press, p. 353-382.

GRÖNBLAD, R. 1945. De algus brasiliensibus: praecipue Desmidiacius, in regione inferiore fluminis Amazonas. Acta Societatis Scientiarum Fennicae 2: 1-43.

GUILLE, A. 1970. Benthic bionomy of continental shelf of the french Catalane Coast. II. Benthic communities of the macrofauna. Vie et Milieu 21:149-280.

LAM, P.K.S. \& LEI, A. 1999. Colonization of periphytic algae on artificial substrates in a tropical stream. Diatom Research 14: 307-322.

LOPES, M.R.M. \& BICUDO, C.E.M. 2002. Desmidioflórula de um lago da planície de inundação do Rio Acre, Estado do Amazonas, Brasil. Acta Amazonica 33:167-212.

MARTINS, D.V. 1980. Desmidioflórula dos Lagos Cristalino e São Sebastião, estado do Amazonas. Manaus, Amazonas. Thesis, Instituto Nacional de Pesquisas da Amazônia, Manaus.

MARTINS, D.V. 1986. Gêneros Euastrum Ehrenberg, Micrasterias Agardh e Triploceras Bailey (Desmidiaceae) dos lagos Cristalino e São Sebastião, Estado do Amazonas, Brasil. Universitas 38:43-58.

McCOURT, R.M., KAROL, K.G., BELL, J., HELM-BYCHOWSKI, K.M., GRAJEWSKA, A., WOJCIECHOWSKI, M.F. \& HOSHAW, R.W. 2000. Phylogeny of the conjugating green algae (Zygnemophyceae) based on rbcL sequences. Journal of Phycology 36: 747-758.

MELO, S., REBELO, S.R.M., SOUZA, K.F., SOARES C.C. \& SOPHIA, M.G. 2005. Desmídias com ocorrência planctônica. In Biotupé: meio físico, diversidade biológica e sócio-cultura do baixo rio Negro, Amazônia Central (SANTOS SILVA, E.N., APRILE, F.M., SCUDELLER, V.V. \& MELO, S. eds.). Manaus: INPA. Pp.100-108.

MELO, S., SOUZA, F.K., REBELO, S.R.M. \& SOPHIA, M.G. 2009. Gêneros Euastrum Ehrenberg ex Ralfs e Micrasterias C. Agardh (Conjugatophyceae-Desmidiaceae) de dois ambientes amazônicos de águas pretas (Manaus, Amazonas-Brasil). Acta Amazonica 39:13-20.

MENEZES, M. \& DIAS, I.C.A. 2001. Biodiversidade de algas de águas continentais do Estado do Rio de Janeiro. Rio de Janeiro: Museu Nacional, Série Livros 9.

MILLER, M.C., DeOLIVEIRA, P. \& GIBEAU, G.G. 1992. Epilithic diatom community response to years of $\mathrm{PO}_{4}$ fertilization Kuparuk River, Alaska (68 N Lat.). Hydrobiologia 240:103-119.

MIX, M. 1973. Die Feinstruktur der Zellwände der Conjugaten und ihre systematische Bedeutung. Beih. Nova Hedwigia 42:179-194.

MORESCO, C., BIOLO, S. \& BUENO, N.C. 2009. O gênero Micrasterias Agardh ex Ralfs (Desmidiaceae, Zygnemaphyceae) em um lago artificial urbano, Paraná, Brasil. Hoehnea 36:349-358.

NOGUEIRA, I.S. 1999. Estrutura e dinâmica da comunidade fitoplanctônica da represa Samambaia, Goiás, Brasil. Thesis, Universidade de São Paulo, São Paulo.

NORDSTEDT, O. 1869. Symbolae ad floram Brasiliae centrals congnoscedam. Öfversigt af Kungliga Vetenskapsakademiens förhandlingar (14-15): 195-234.

OLIVEIRA, I.B., BICUDO, C.E.M. \& MOURA, C.W.N. 2011. Euastrum (Desmidiaceae, Zygnematophyceae) na planície litorânea do norte da Bahia, Brasil. Sitientibus 11:62-73.

OLIVEIRA, I.B., MOURA, C.W.N. \& BICUDO, C.E.M. 2009. Micrasterias C. Agardh ex Ralfs (Zygnematophyceae) de duas Áreas de Proteção Ambiental da planície litorânea do norte da Bahia, Brasil. Revista Brasileira de Botânica 32:213-232. 
PEEL, M.C., FINLAYSON, B.L. \& MCMAHON, T.A. 2007. Updated world map of the Köppen-Geiger climate classification. Hydrology and Earth System Sciences 11:1633-1644.

SOPHIA, M.G. 1989. Contribuição do gênero Micrasterias C. Agardh ex Ralfs (Zygnemaphyceae) do Estado do Rio de Janeiro. Hoehnea 16:65-87.

SORMUS, L. \& BICUDO, C.E.M. 1997. Criptógamos do Parque Estadual das Fontes do Ipiranga, São Paulo, SP. Algas, 10: Zygnemaphyceae (Desmidiaceae, Micrasterias). Hoehnea 24: 75-87.
SOUZA, D.B.S. \& FELISBERTO, S.A. 2014. Comasiella, Desmodesmus, Pectinodesmus e Scenedesmus na comunidade perifítica em ecossistema lêntico tropical, Brasil Central. Hoehnea 41(1):109-120.

STEVENSON, R.J. 1996. Algal Ecology: Freshwater Benthic Ecosystems. Academic Press, San Diego, Califórnia.

UHERKOVICH, G. 1981. Algen aus einigen Gewaessern Amazoniens. Amazoniana 7:191-219.

WETZEL, R.G. 1983. Recommendations for future research on periphyton. In Periphyton of freshwater ecosystems. (WETZEL, R.G. ed.). The Hague, Dr. W. Junk, p. 339-346.

Received 05/03/2015

Revised 05/03/2015

Accepted 16/03/2015 